\title{
Glucagon Receptor
}

National Cancer Institute

\section{Source}

National Cancer Institute. Glucagon Receptor. NCI Thesaurus. Code C157480.

Glucagon receptor (477 aa, $\sim 54 \mathrm{kDa}$ ) is encoded by the human GCGR gene. This protein plays a role in the glucagon-dependent regulation of blood glucose levels. 